\title{
Unravelling Role of Edaphic Stress on Development of Phytophthora Blight (Phytophthora cajani) in Pigeonpea
}

\author{
G. Jadesha ${ }^{1,2^{*}}$, Mamta Sharma ${ }^{1}$ and Narayan Reddy ${ }^{2}$ \\ ${ }^{1}$ Department of Legumes Pathology, International Crops Research Institute for the Semi-Arid \\ Tropics, Patancheru, India \\ ${ }^{2}$ Department of Plant Pathology, Professor Jayashankar Telangana State Agricultural \\ University, Hyderabad, India \\ *Corresponding author
}

\section{A B S T R A C T}

\section{Keywords}

Edaphic stress,

Flooding,

Phytophthora blight and Pigeonpea

Article Info

Accepted:

12 November 2019

Available Online:

10 December 2019
The relation between soil moisture content (SMC) and development of phytophthora blight disease of pigeonpea was determined. Among all the SMC, flooding condition yielded the highest occurrence of disease with shortest incubation period (IP). Further assay to ascertain the duration of flooding and disease progress, result shows minimum of 24 hours of flooding is sufficient to initiate the disease with IP period of 24 hours. Among the soil type, black clay soil has produced the high disease incidence compare to red loamy soil. Further, an interaction of different level of inoculums density $\left(1 \times 10^{-1}\right.$ to $\left.1 \times 10^{-6}\right)$ and soil moisture content shows, even low level of inoculum density is sufficient to cause infection in the host plants under flooded condition, whereas high level of inoculum density and lengthiest IP period is required to cause infection in the host in field capacity of the soil. The study helps in understand the biology of Phytophtohra cajani in relation to soil moisture content and ultimately developing appropriate cultural strategies for management of disease efficiently.

\section{Introduction}

Pigeonpea (Cajanus cajan L.) is commonly known as redgram. The seeds are used as dal which is rich in protein $(21 \%)$, iron, iodine and essential amino acids like lysine, tyrosine, cystine and arginine. Pigeonpea when rotated with cereal crops increases the yield of cereals by enhancing soil nitrogen and helps in breaking the disease cycle of important cereal pathogens. Because of its tolerance to heat and drought, it is suitable for low-fertility soils. Globally, Pigeonpea is cultivated in 5.41 million ha, adding 4.49 million tonnes of grain 
to the global food basket. India alone accounts 72.50 per cent of area with 62.54 per cent of production (FAO, 2016)

Phytophthora blight is caused by Phytophthora cajani. The first suspected occurrence of phytophthora blight on pigeonpea in India was first reported in 1966 by Williams et al., (1968). Recently, the recurrence of phytophthora blight was reported and has become a major threat to pigeonpea production and productivity in the Deccan Plateau of India irrespective of cropping system, soil types and cultivars (Pande et al., 2011). The effect of Phytophthora blight on grain yield depends on the appearance of the disease during the crop growth period which largely depend on weather conditions and inoculum levels of the pathogen.

Chemical industry and plant breeders develop the weapons but the epidemiologists set the strategy (Van der plank, 1963). Epidemiological studies generate lot of information on different aspects of disease development. This processed data helps in developing appropriate strategies for plant disease management. Different environmental factors like soil physical conditions, water relations and interacting combinations of these factors have been reported to influence Phytophthora pathogenesis (Duniway, 1983). Soil moisture is considered as an important factor for disease development specially caused by Phytophthora spp. However with respect to Phytophthora blight of pigeonpea, there are contradicting reports available in literature. Williams et al., (1975) correlated high incidence of PB of Pigeonpea in poor soil surface drainage, other hand Singh and Chauhan (1985) reported PB disease developing to an epidemic level in well aerated soils. Similarly, Pande et al., (2009) pointed the outbreak of PB in well drained, partially drained and temporarily water logged fields across the soil types, cropping systems and cultivars.

Many authors are of the opinion that, low lying, poorly drained soil was conducive for the incidence of Phytophthora blight as it promote high soil moisture (Kannaiyan et al., 1984; Mishra and Shukla 1987 and Chauhan et al., 2002; Masood et al., 2005; Sharma et $a l ., 2006)$. The water holding capacity of soil is a function of soil profile. Few authors proposed a correlation between soil profile and Phytophthora incidence. Goodall et al., (1962) correlated incidence of Phytophthora root rot in avocado with soil profile characteristics.

Their research outcome implied recent alluvial soils are the safest while the old terrace soils are the most hazardous to disease development. The texture of the soil also influenced on disease incidence, where loam, sandy loam and clay showed the incidence of 20, 17 and 3 per cent respectively. Further, Masood et al., (2005) reported that Phytophthora blight disease appeared both in vertisols and alfisols.

Literature depicts flooding in many host pathogen system increases the disease incidence by favouring the induction of sporangia and movement of zoospore and modifying host to susceptible condition. Hence proper drainage of Pigeonpea fields and growing piogeonpea in well elevated or well drained fields can be advised.

Sowing of crop on raised beds and proper drainage of fields are the suggestive agronomic practices to reduce Phytophthora blight incidence, since water logging is believed to predispose Pigeonpea crop to Phytophthora blight under favourable environmental conditions (Singh and Chauhan, 1985; Reddy et al., 1991; Sharma et al., 2006). 


\section{Materials and Methods}

The present investigations were carried out during 2012-13 and 2013-14 in the laboratory and greenhouse conditions at Legumes Pathology, International Crops Research Institute for the Semi-Arid tropics (ICRISAT), Patancheru.

\section{Plant growth conditions}

Susceptible cultivar (ICP 7119) of Pigeonpea was grown in the plastic pots $(12 \mathrm{~cm})$ filled with a mixture of sterilized alfisol comprising of $60 \%$ sand, $33 \%$ clay and $7 \%$ silt (Kannaiyan et al., 1981) kept in a greenhouse maintained at $28-30^{\circ} \mathrm{C}$ for 10 days. Before sowing, seeds are surface sterilized using $2 \%$ sodium hypochlorite for 2 minutes and rinsed in sterile water in order to wash off sodium hypochlorite.

\section{Phytophthora cajani}

Pigeonpea plants showing the typical symptoms of Phytophthora blight were collected and isolation of pathogen was done according to tissue segment method (Rangaswamy, 1958). Stem bits consisting of 50 per cent infected and 50 per cent healthy were surface sterilized using 1 per cent sodium hypochlorite $(\mathrm{NaOCl})$ for 60 seconds and then washed in sterile water thrice. The stem bits were blot dried and plated on petri plate containing V8 juice agar media (Himedia, Mumbai, India) amended with PARP antibiotics (pimarcin $400 \mu \mathrm{L}$; ampicillin $250 \mathrm{mg} ; \quad$ rifampicin $1000 \mu \mathrm{L}$; and pentachloronitrobenzine $5 \mathrm{mlL}-1$ media). Plates were incubated at $30^{\circ} \mathrm{C}$ in the $12 \mathrm{~h} / 12 \mathrm{~h}$ day-night photoperiod for 5 days. Putative Phytophthora colonies were selected and confirmed by cultural and morphological characteristics as described by (Erwin and Ribeiro, 1996). The fungus was subcultured and maintained on tomato extract agar slants under in vitro at $15 \pm 1^{\circ} \mathrm{C}$ in dark condition by regular sub culturing after 15-20 days. Pathogenicity of fungus was established by proving the Koch's postulates on the highly susceptible cultivar ICP 7119 (Reddy et al., 1991) in controlled conditions. Virulence of the pathogen was maintained by transferring the pathogen through susceptible host after every 60 days.

\section{Inoculation}

Soil mixing method of inoculation was done as described by Pande et al., (2012), where inoculum multiplied by transferring $6 \mathrm{~mm}$ disc growth of $P$. cajani to 100 gram of sterilized pigeonpea sand flour medium in $250 \mathrm{ml}$ flasks and incubated at $30{ }^{\circ} \mathrm{C}$ with 12 hours of alternate light (2000 Lux) and dark condition for 2 weeks. Inoculum multiplied on pigeonpea sand flour medium was directly mixed into the soil without disturbing the roots of the seedling on 10 day old seedlings in the pot. Each pot containing 10 seedlings constituted one replication and all the experiments was replicated thrice.

\section{Edaphic stress and disease development}

\section{Soil moisture}

An experiment was conducted with soil moisture regimes, viz. 60 per cent, 80 per cent, 100 per cent moisture at field capacity and flooding condition to study the development of disease under controlled conditions using susceptible cultivar ICP7119. Uninoculated control was maintained for each soil moisture level. Deionized water was used for maintaining the soil moisture content in each treatment.

The soil moisture content (SMC) was determined as per the procedure of Sharma and Pande (2013) using the gravimetric method on oven-dry basis. The soil sample 
was saturated and later soil moisture was removed by oven drying $\left(100-110^{\circ} \mathrm{C}\right)$ until the weight remains constant. The samples were removed from the oven and brought to room temperature and weighed again. The difference in weight was considered as amount of moisture in the soil. The available SMC in the soil was calculated by the following formula Soil moisture content $(\%)=$ (Saturated soil weight - Oven dry soil weight/ Oven dry soil weight $) \times 100$. The four levels of SMC (60\%, 80\%, 100\% and flooding) was adjusted by maintaining the constant weight by regular weighing and replacing the moisture deficit in each pot by watering (Suriachandraselvan and Seetharaman, 2003).

\section{Post inoculation flooding}

To know the role of post flooding on disease development, an experiment was conducted as described by Barta, (1986) involving seven treatments T1-Post inoculation flooding for 24 Hours; T2- Post inoculation flooding for 48 Hours; T3- Post inoculation flooding for 72 Hours; T4- Post inoculation flooding for 4 days; T5- Post inoculation flooding for 5 days: T6- Flooding uninoculated: T7- NonFlooding.

Each pot containing 10 seedlings constituted one replication and the experiment was replicated thrice. Growing of seedlings and inoculum multiplication and method of inoculation were same as explained earlier. The data on per cent disease incidence and incubation period was calculated.

\section{Soil type}

The soil type and development of phytophthora blight disease was conducted by sowing susceptible variety ICP 7119 in black clay and red loamy soil under pot conditions and incubated in greenhouse. Growing of seedlings and inoculum multiplication and method of inoculation were same as explained earlier. The data on per cent disease incidence and incubation period was calculated.

\section{Interaction of inoculum dose and soil moisture regime}

Ten day old seedlings were inoculated with zoospores with different inoculum concentrations viz., $1 \times 10^{-1}, 1 \times 10^{-2}, 1 \times 10^{-3}$ $1 \times 10^{-4}, 1 \times 10^{-5}$ and $1 \times 10^{-6}$ zoospores $/ \mathrm{ml}$. Five $\mathrm{ml}$ of inoculum containing different concentrations of zoospores was inoculated to seedlings. Before inoculating the plants, pots were flooded with deionised water up to collar region of plants. Soil moisture regimes of 100 per cent moisture at field capacity and flooding condition were maintained as explained earlier. The incubation period and disease incidence was recorded everyday up to the complete mortality. Each pot containing 10 seedlings constituted one replication and the experiments was replicated twice.

\section{Results and Discussion}

Scanty information is available on soil moisture relation to biology of Phytophthora cajanai and epidemiology of disease. Epidemiology and disease development and cultural strategies to manage the disease made an impetus to undertake the present investigation with these objectives in view.

\section{Soil moisture $\times$ Pigeonpea $\times$ Phytophthora cajani}

Soil moisture status is an important factor in biology of Phytophthora spp. Poor soil aeration and prolonged soil saturation enhances reproduction and dissemination of Phytophthora (Agrios, 2005). Present study, four soil moisture regimes, viz. 60 per cent, 80 per cent, 100 per cent of field capacity and flooding condition was applied to evaluate occurrence and development of disease in pot 
culture study (Fig. 1). With increase in soil moisture there was an increase in incidence of the disease further decrease in incubation period. Flooding condition induced the disease appearance in acute when compare to any level of field capacity similarly intensity of disease development with time was greatest (Table 1). Early infection and high disease incidence in flooding condition because of available free water helped in production of sporangia and movement of zoospores. Similar reports have reported by Peries and Fernando (1972) in Phytophthora meadii where zoospores liberated only in the presence of free water and germinated poorly and produced little germ-tube growth on dry surfaces.

\section{Flooding duration $\times$ Pigeonpea $\times$ Phytophthora cajani}

Excess irrigation and rainfall are considered to be the most important factors that increase the severity and spread of Phytophthora incited diseases. In turn, the duration of free water in soil is the most important environmental factor in the development of disease caused by Phytophthora because it is during this time that propagules proliferate and infect (Erwin and Ribeiro, 1996). In addition, zoospores travel in the soil in irrigation water, rainfall run-off and movement of soil. Phytophthora diseases are multicyclic, under congenial environmental conditions inoculum may amplify rapidly and cause infection. The increase in folds of inoculum from low to high levels within a few days is caused by the rapid production of sporangia and zoospores at the surface of infected plant tissues. The acute regeneration time and great reproductive capacity cause Phytophthora diseases may develop epidemically when the soil remains excessively wet for prolonged periods (Erwin and Ribeiro, 1996). The experiment was carried out to examine the role of post inoculation flooding on early infection and disease development. Minimum of 24 hours of post inoculation flooding is sufficient to cause plant infection whereas minimum of 72 hours are required for maximum disease incidence and complete mortality of host plants (Table 2). The similar results are reported by Duniway (1977) in Phytophthora root rot in safflower, Baker and Macdonald (1981) in Phytophthora root and crown rot of Rhododendron and Barta, (1986) in Phytophthora root rot of alfalfa. The occurrence of Phytophthora in flooded soils has been attributed to requirements of the pathogen for high soil moisture (Zentmyer, 1980). Flooding either increases the production and dispersion of inoculum or negatively affects root metabolism, thus facilitating infection and growth within the diseased tissue. Members of this genus reproduce by formation of sporangia which, under proper conditions, germinate to release free-swimming zoospores. The zoospores of Phytophthora are chemotactic and can swim to plant roots to establish new infections.

To conclude, flooding conditions predispose the pigeonpea to the Phytophthora blight hence, pigeonpea should be sown in welldrained soil and not subject to flooding, proper drainage of fields to reduce the rate and extent of build-up of inoculum, and sowing of crop on raised beds, avoidance of sowing of pigeonpea in low laying fields are the suggestive agronomical practices to reduce phytophthora blight incidence.

\section{Soil type $\times$ Pigeonpea $\times$ Phytophthora cajani}

The interaction of soil type viz., black and red sandy loam soil, host and pathogen was assessed on development of disease. Red loamy soil cause early infection and maximum disease pressure over black clay soil (Fig. 2) because of red loamy soil will aid in movement of zoospores and cause for new infection. 
Table.1 Interaction of soil moisture content, Phytophthora cajani and Pigeonpea host plant

\begin{tabular}{|c|c|c|c|c|c|c|c|c|}
\hline \multirow[t]{2}{*}{ S. No. } & \multirow{2}{*}{$\begin{array}{c}\text { SMC }^{*} \\
(\%)\end{array}$} & \multirow{2}{*}{$\begin{array}{c}\text { IP } \\
\text { (Hour) }\end{array}$} & \multicolumn{6}{|c|}{ PDI at different post inoculation days** } \\
\hline & & & 1 & 3 & 5 & 10 & 15 & 20 \\
\hline 1 & 60 & 72 & $\begin{array}{c}0.0^{\mathrm{b}} \\
(0.9)\end{array}$ & $\begin{array}{c}0.0^{b} \\
(0.9)\end{array}$ & $\begin{array}{c}1.9^{\mathrm{d}} \\
(4.6)\end{array}$ & $\begin{array}{l}20.6^{b} \\
(26.1)\end{array}$ & $\begin{array}{l}22.5^{\mathrm{c}} \\
(27.3)\end{array}$ & $\begin{array}{l}22.5^{\mathrm{c}} \\
(0.9)\end{array}$ \\
\hline 2 & 80 & 72 & $\begin{array}{c}0.0^{\mathrm{b}} \\
(0.91)\end{array}$ & $\begin{array}{c}0.0^{\mathrm{b}} \\
(0.91)\end{array}$ & $\begin{array}{c}6.6^{c} \\
(14.6)\end{array}$ & $\begin{array}{l}21.2^{\mathrm{b}} \\
(26.5)\end{array}$ & $\begin{array}{l}25.1^{\mathrm{c}} \\
(28.8)\end{array}$ & $\begin{array}{l}25.1^{\mathrm{c}} \\
(28.8)\end{array}$ \\
\hline 3 & 100 & 60 & $\begin{array}{l}3.1^{\mathrm{b}} \\
(5.8)\end{array}$ & $\begin{array}{c}19.4^{\mathrm{b}} \\
(14.2)\end{array}$ & $\begin{array}{l}28.4^{b} \\
(26.5)\end{array}$ & $\begin{array}{l}40.2^{b} \\
(37.3)\end{array}$ & $\begin{array}{c}50.3^{b} \\
(43.0)\end{array}$ & $\begin{array}{c}50.3^{\mathrm{b}} \\
(43.0)\end{array}$ \\
\hline 4 & Flooding & 30 & $\begin{array}{c}9.4^{\mathrm{a}} \\
(15.5)\end{array}$ & $\begin{array}{l}50.6^{\mathrm{a}} \\
(37.2)\end{array}$ & $\begin{array}{c}100^{\mathrm{a}} \\
(71.3)\end{array}$ & $\begin{array}{c}100^{\mathrm{a}} \\
(71.3)\end{array}$ & $\begin{array}{c}100^{\mathrm{a}} \\
(71.3)\end{array}$ & $\begin{array}{c}100^{\mathrm{a}} \\
(71.3)\end{array}$ \\
\hline 5 & Control & 0 & $\begin{array}{l}0.0^{\mathrm{b}} \\
(0.9)\end{array}$ & $\begin{array}{l}0.0^{\mathrm{b}} \\
(0.9)\end{array}$ & $\begin{array}{l}0.0^{\mathrm{d}} \\
(0.9)\end{array}$ & $\begin{array}{l}0.0^{\mathrm{c}} \\
(0.9)\end{array}$ & $\begin{array}{l}0.0^{\mathrm{d}} \\
(0.9)\end{array}$ & $\begin{array}{l}0.0^{\mathrm{d}} \\
(0.9)\end{array}$ \\
\hline
\end{tabular}

*SMC -Soil moisture content, **Mean of three replications, Figures in parentheses are arcsine transformed values. Means followed by a common letter are not significantly different at 5\% level by Tukey's (HSD)

Table.2 Unravel the effect of flooding duration on development of PB of Pigeonpea

\begin{tabular}{|c|c|c|c|c|c|c|c|c|c|}
\hline \multirow{2}{*}{$\begin{array}{c}\text { Treat } \\
\text { ment }\end{array}$} & \multicolumn{7}{|c|}{ Soil mixing method of inoculation } \\
\cline { 2 - 9 } & \multicolumn{7}{|c|}{ Per cent disease incidence at different days after inoculation* } \\
\cline { 2 - 9 } & 1 & 2 & 3 & 4 & 5 & 6 & 7 & 25 \\
\hline T-1 & $0.0^{\mathrm{a}}$ & $24.7^{\mathrm{b}}$ & $37.2^{\mathrm{c}}$ & $40.2^{\mathrm{c}}$ & $40.2^{\mathrm{f}}$ & $46.4^{\mathrm{d}}$ & $49.7^{\mathrm{c}}$ & $49.7^{\mathrm{c}}$ \\
& $(0.9)$ & $(28.6)$ & $(35.4)$ & $(36.9)$ & $(36.9)$ & $(39.8)$ & $(41.3)$ & $(41.3)$ \\
\hline \multirow{2}{*}{ T-2 } & $0.0^{\mathrm{a}}$ & $24.6^{\mathrm{b}}$ & $31.2^{\mathrm{e}}$ & $40.4^{\mathrm{c}}$ & $49.9^{\mathrm{e}}$ & $59.0^{\mathrm{c}}$ & $59.0^{\mathrm{b}}$ & $59.0^{\mathrm{b}}$ \\
& $(0.9)$ & $(28.6)$ & $(32.3)$ & $(37.0)$ & $(41.4)$ & $(45.5)$ & $(45.5)$ & $(45.5)$ \\
\hline T-3 & $0.0^{\mathrm{a}}$ & $27.9^{\mathrm{a}}$ & $49.8^{\mathrm{a}}$ & $68.4^{\mathrm{b}}$ & $77.8^{\mathrm{c}}$ & $90.7^{\mathrm{b}}$ & $100.0^{\mathrm{a}}$ & $100.0^{\mathrm{a}}$ \\
& $(0.9)$ & $(30.5)$ & $(41.4)$ & $(49.7)$ & $(54.1)$ & $(61.1)$ & $(71.3)$ & $(71.3)$ \\
\hline T-4 & $0.0^{\mathrm{a}}$ & $24.7^{\mathrm{b}}$ & $50.2^{\mathrm{a}}$ & $68.5^{\mathrm{b}}$ & $81.1^{\mathrm{b}}$ & $100.0^{\mathrm{a}}$ & $100.0^{\mathrm{a}}$ & $100.0^{\mathrm{a}}$ \\
& $(0.9)$ & $(28.6)$ & $(41.5)$ & $(49.8)$ & $(55.7)$ & $(71.3)$ & $(71.3)$ & $(71.3)$ \\
\hline T-5 & $0.0^{\mathrm{a}}$ & $27.9^{\mathrm{a}}$ & $43.5^{\mathrm{b}}$ & $81.2^{\mathrm{a}}$ & $93.4^{\mathrm{a}}$ & $100.0^{\mathrm{a}}$ & $100.0^{\mathrm{a}}$ & $100.0^{\mathrm{a}}$ \\
& $(0.9)$ & $(30.5)$ & $(38.4)$ & $(55.8)$ & $(62.9)$ & $(71.3)$ & $(71.3)$ & $(71.3)$ \\
\hline T-6 & $0.0^{\mathrm{a}}$ & $0.0^{\mathrm{d}}$ & $0.0^{\mathrm{f}}$ & $0.0^{\mathrm{f}}$ & $0.0^{\mathrm{h}}$ & $0.0^{\mathrm{e}}$ & $0.0^{\mathrm{e}}$ & $0.0^{\mathrm{e}}$ \\
& $(0.9)$ & $(0.9)$ & $(0.9)$ & $(0.9)$ & $(0.9)$ & $(0.9)$ & $(0.9)$ & $(0.9)$ \\
\hline T-7 & $0.0^{\mathrm{a}}$ & $0.0^{\mathrm{d}}$ & $0.0^{\mathrm{f}}$ & $0.0^{\mathrm{f}}$ & $0.0^{\mathrm{h}}$ & $0.0^{\mathrm{e}}$ & $0.0^{\mathrm{e}}$ & $0.0^{\mathrm{e}}$ \\
& $(0.9)$ & $(0.9)$ & $(0.9)$ & $(0.9)$ & $(0.9)$ & $(0.9)$ & $(0.9)$ & $(0.9)$ \\
\hline
\end{tabular}

T1- Post inoculation flooding for 24 Hours : T2- Post inoculation flooding for 48 Hours T3- Post inoculation flooding for 72 Hours: T4- Post inoculation flooding for 4 days

T5- Post inoculation flooding for 5 days: T6- Flooding uninoculated: T7- Non-Flooding 
Fig.1 Soil moisture content $\times$ Phytophthora cajani $\times$ Pigeonpea host plant

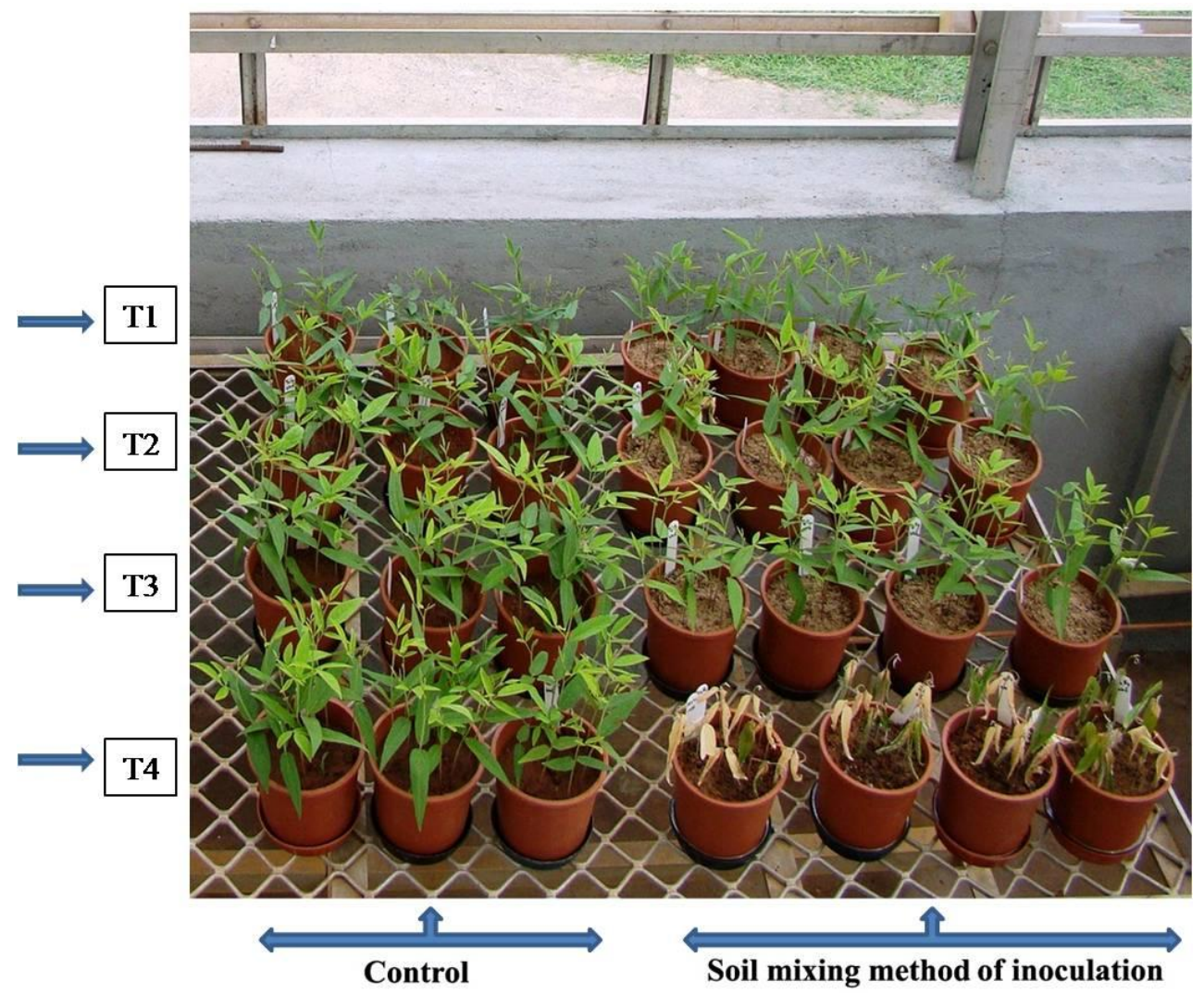

Treatments: T1- 60 Per cent SMC, T-2 80 Per cent SMC, T3- 100 Per cent SMC and T-4 Flooding

Fig.2 Soil type and incidence of phytophthora blight of pigeonpea in greenhouse conditions

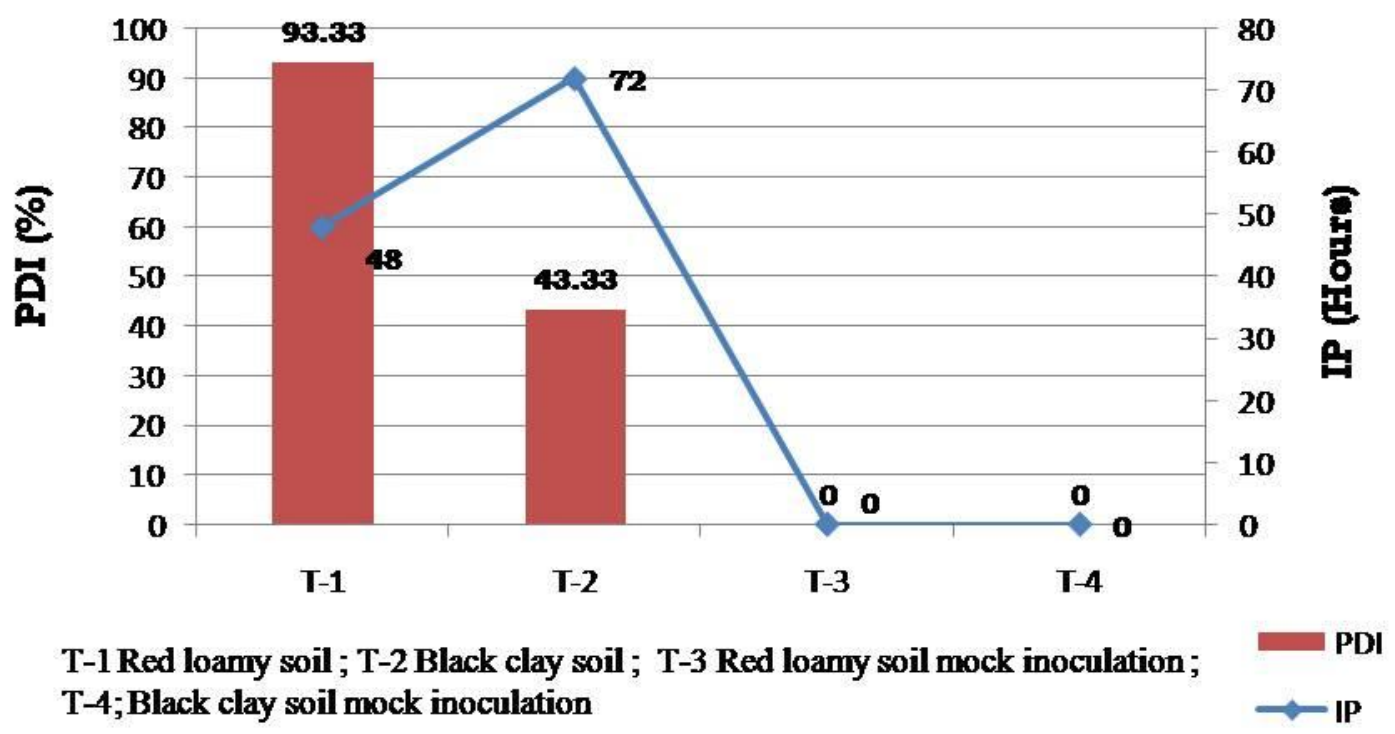


Fig.3 Interaction of soil moisture content and inoculums density on severity of PB of pigeonpea

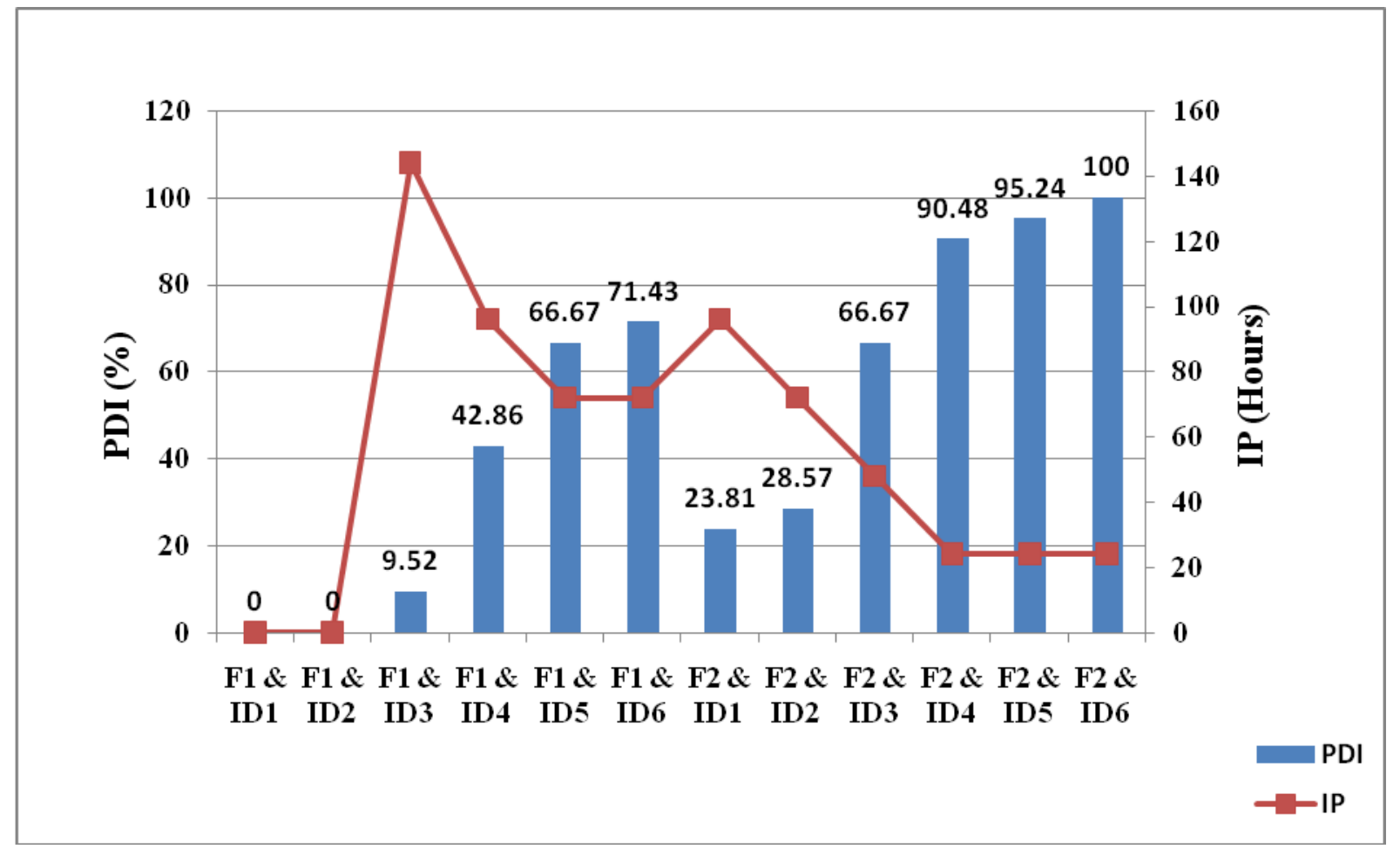

Goodall (1962) proposed the incidence of Phytophthora root rot in avocado with texture of the soil and reported severity of the disease was high in sandy loam soil compared to clay soil as sandy loamy soil aid in movement of zoospores and establishes a new infections.

\section{Soil moisture content $x$ inoculums density on severity of phytophthora blight}

To determine the role of soil moisture content on early infection and development of phytophthora blight disease, different dose of inoculum was selected with different soil moisture content. Quantity of inoculum is bound to influence the disease incidence and infection takes place only when minimum inoculum potential of the pathogen is present in the soil. In the study, it was observed that with the increase in quantity of inoculum there was substantial increase in the infection in flooding conditions (Fig. 3). Further low level of inoculums density viz., $1 \times 10^{-1}$ and $1 \times 10^{-2}$ could not able to initiate the infection in the host plants in $100 \%$ field capacity of soil moisture content whereas infection of 23.81 and 28.57 per cent was observed ten days after post inoculation in inoculums dose of $1 \times 10^{-1}$ and $1 \times 10^{-2}$ respectively under flooding conditions. The study in toto reveals, In flooding conditions even low level of inoculum density $\left(1 \times 10^{-1}\right)$ is sufficient to cause infection in the host plants with shortest IP whereas high level of inoculum density $\left(1 \times 10^{-3}\right)$ and lengthiest IP period is required to cause infection in the host in $100 \%$ field capacity of soil moisture content. Low level of inoculums could cause infection in flooding conditions is because of availability of free water for induction of sporangia sand zoospores and also dissemination of zoospores to host plant for infection site. Species of Phytophthora require high levels of soil moisture to produce and release zoospores (Bernhardt and Grogan, 1982). Hence, the availability of free water has greater concern 
for pigonpea production since even in low level of inoculums cause the early infection and spread of disease in rampant manure and cause mortality of plants ultimately economic yield loss. Hence cultural management like sowing of crop in the well drained soil and avoiding the selection of low laying area will help in managing the disease effectively.

\section{Acknowledgement}

The funding support from Indian Council of Agricultural Research (ICAR), New Delhi, is gratefully acknowledged.

\section{References}

Agrios, G.N., 2005. Plant Pathology, Academic Press, San Diego, CA. 635636.

Baker, M. S., and MacDonald, J. D. 1981. Predisposing effects of soil moisture extremes on the susceptibility of rhododendron to Phytophthora root and crown rot. Phytopathology.71: 831-834.

Barta, A.L., 1986. Interaction between flooding stress and Phytophthora root rot among alfalfa cultivars. Plant disease . 70: 310-313.

Bernhardt, E. A. and R. G. Grogan. 1982. Effect of soil matric potential on the formation and indirect germination of sporangia of Phytophthora parasitica, $P$. capsici, and $P$. cryptogea. Phytopathology. 72: 507-511.

Chauhan, V.B., Singh, V.B. and Singh, A.K. 2002. Evaluation of Pigeonpea genotype for resistance to Phytophthora blight. International Chickpea and Pigeonpea Newsletter.9: 42.

Duniway, J. M., 1977. Predisposing of effect of water stress on the severity of Phytophthora root rot in safflower. Phytopathology. 67: 884-889.
Duniway, J. M., 1983. Effects of temperature, concentration, age, and algaecides on Phytophthora capsici zoospore infectivity. In. D. C. Erwin, S. Bartnicki-Garcia and P. H. Tsao. Phytophthora: Its Biology, Taxonomy, Ecology, and Pathology. Plant Disease. 94: 54-60.

Erwin, D. C., and Ribeiro, O. K. 1996. Phytophthora diseases worldwide. American Phytopathological Society, St. Paul, MN.

FAO., 2016. FAO Year book (Production). Food and Agriculture Organization of the United Nations.

Goodall, G. E. Hansen, D. M. and Burns, R. M. 1962. Santa barbara county avocado root rot soil survey. California Avocado Society, Yearbook. 46: 63-71.

Kannaiyan, J., Nene, Y.L., Raju, T.N. and Sheila, V.K. 1981. Screening for resistance to Phytophthora blight of Pigeonpea. Plant Disease. 61-62.

Kannaiyan, J., Nene, Y L., Reddy, M V., Ryan, J G and Raju, T N. 1984. Prevalence of Pigeonpea diseases and associated crop losses in Asia, Africa and the Americas. Tropical Pest Management. 30 (1): 62-71.

Masood, A, Singh, B.B., Kumar, S. and Vishwa Dhar. 2005. Advances in Pigeonpea research. Indian Society of Pulses Research and Development, IIPR, Kanpur, India. 229-261.

Mishra, A.N and Shukla, P. 1987. Prevalence of Phytophthora blight of Pigeonpea in Uttar Pradesh. Indian Phytopathology. 40: 56-58.

Pande, S. Sharma, M, Mangla, U. N. Ghosh, R, Sundaresan, G. 2011. Phytophthora blight of Pigeonpea [Cajanus cajan (L.) Millsp.]: An updating review of biology, pathogenicity and disease management. Crop Protection. 30: 951-957. 
Pande, S., Sharma, M., 2009. Status of resistance to Phytophthora blight in the improved Pigeonpea lines and hybrids at ICRISAT, Patancheru. Legumes Pathology Progress Report, ICRISAT, Patancheru, Andhra Pradesh. India.

Pande, S., Sharma, M., Guvvala, G. and Telangre, R. 2012. High throughput phenotyping of Pigeonpea diseases: Stepwise identification of host plant resistance. Information bulletin. ICRISAT, 93: 19-20.

Peries, O. S., and Fernando T. M., 1972. Studies on the biology of Phytophthora meadii. Rubber Research Institute Ceylon. 49: 13-27.

Rangaswami, G., 1958. An agar blocks technique for isolating soil microorganisms with special reference to Pythiaceous fungi. Science and Culture. 24: 85.

Reddy, M.V., Sarkar, N., Nene, Y.L., Raju, T.N. 1991. Predisposing factors for Phytophthora blight of Pigeonpea. Indian Phytopathology. 268-270.

Sharma, M., Pande, S., Pathak, M., Narayana Rao, Anilkumar, P., Madhusudhan, D., Benagi, V.I., Mahalinga, D.M., Zhote, K.K., Karanjkar, P.N., and Eksinghe, B.S. 2006. Prevalence of Phytophthora blight in the Deccan Plateau in India. Plant Pathology Journal. 22(4): 309313.

Sharma, M., Pande, S., 2013. Unravelling Effects of Temperature and Soil
Moisture Stress Response on Development of Dry Root Rot [Rhizoctonia bataticola (Taub.)] Butler in Chickpea. American Journal of Plant Sciences. 4, 584-589. doi:10.4236/ajps.2013.43076.

Singh, U.P., Chauhan, V.B., 1985. Relationship between field levels and light and darkness on the development of Phytophthora blight of Pigeonpea (Cajanus cajan (L.)Millsp.)

Phytopathology. 114: 160-167.

Suriachandraselvan. M. and Seetharaman, K. 2003. Factors influencing susceptibility of sunflower to charcoal rot disease caused by Macrophomina phaseolina. Journal of Mycology and Plant Pathology. 33(2): 252-256.

Van der Plank, J. E., 1963. Plant disease: Epidemics and control. Academic Press, New York.

Williams, F J., Amln, K.S. and Baldev, S. 1975. Phytophthora stem blight of Cajanus cajan. Phytopathology. 65: 1029-1030.

Williams, F.J., Grewal, J.S., Amin, K.S. 1968. Serious and new diseases of pulse crops in India in 1966. Plant Disease Report. 52: 300-304.

Zentmyer. G.A., 1980. Phytophthora cinnamomi and the diseases it causes. Monograph 10. The American Phytopathological Society, St. Paul, MN. 96.

\section{How to cite this article:}

Jadesha, G., Mamta Sharma and Narayan Reddy. 2019. Unravelling Role of Edaphic Stress on Development of Phytophthora Blight (Phytophthora cajani) in Pigeonpea. Int.J.Curr.Microbiol.App.Sci. 8(12): 1336-1345. doi: https://doi.org/10.20546/ijcmas.2019.812.162 